\title{
DEVELOPMENT OF RICE MILLING MACHINE FOR DIFFERENT RICE VARIETIES TO IMPROVE PRODUCT QUALITY
}

Morad, M. M. ${ }^{1}$,

M. M. A. El-Sharabasy ${ }^{3}$

\author{
M. M. Badr' ,
}

E. I. Abdel-Aal ${ }^{3}$

\begin{abstract}
The present research was carried out to develop and estimate some operating parameters and affecting the performance of a rice milling machine to improve product quality. The rice milling machine was developed by adding two units: cleaning unit to remove chaff and other foreign materials from rice grains before the milling operation and feed unit to adjust rice feed rate. The performance of the developed milling machine was studied under the following parameters: feed rate, drum speed, and grain moisture content in terms of overall machine efficiency, total grains losses, machine productivity, required power, specific energy and criterion cost.
\end{abstract} The experimental results reveal that the highest values of machine productivity and overall machine efficiency were $1.08,1.17$ and $1.35 \mathrm{Mg} / \mathrm{h}$; and 95.00, 95.38 and 95.66 \% for Sakha-101, Giza-171 and Sakha-105 varieties, respectively, while the lowest values of required power and specific energy were 13.0, 13.4 and $13.8 \mathrm{~kW}$; and 17.40, 15.68 and $13.85 \mathrm{~kW} . \mathrm{h} / \mathrm{Mg}$, respectively, for the same rice varieties, furthermore the lowest values of both operational and criterion costs were 8.53, 7.87 and 6.82 L.E./Mg; and 35.96, 31.96 and 29.38 L.E./Mg, respectively, for the same rice varieties. Results of mechanical analysis of the manufactured cleaning and feeding units reveal to the following:

- Sieve speed, sieve tilt angle and cleaning air velocity of about 400 rpm, 4.0 deg and $6.5 \mathrm{~m} / \mathrm{s}$.

- Mechanical feeding rate of $1.4 \mathrm{Mg} / \mathrm{h}$ for Sakha-101 variety and $1.6 \mathrm{Mg} / \mathrm{h}$ for both Giza-171 and Sakha-105 varieties.

From the experimented results, it could be concluded that the optimum operating parameters for the developed milling machine were found at:

\footnotetext{
${ }^{1}$ Professor of Agric. Eng., Fac. of Agric., Zagazig Univ., Egypt.

${ }^{2}$ Lecturer of Agric. Eng., Fac. of Agric., Zagazig Univ., Egypt.

${ }^{3}$ Assist. Prof. of Agric. Eng., Fac. of Agric., Zagazig Univ., Egypt.
} 
- Drum speed of about 800 rpm for Sakha-101 and 850 rpm for both Giza-171 and Sakha-105 varieties.

- Grain moisture content of about $14 \%$ for Sakha-101 and $15 \%$ for both Giza-171 and Sakha-105 varieties.

\section{INTRODUCTION}

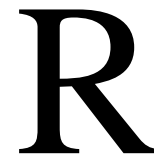
ice crop is considered one of the most important economical crops as it participates in the national income added to the local removing the hulls and bran from the harvested and dried rough rice to produce white rice with minimum percentage of broken grains and impurities. The broken grains cause a loss because they have lower market price. So, during rice milling process, controlling in factors affecting the quality of grain rice is attractive effort. The output of milled rice and its quality are highly affected by the milling degree to remove the outer layer of the rice (bran). Physical and engineering properties of grains have to be considered to study their effect on the performance of the milling machine. El-Raie et al. (1996) studied some mechanical properties of grains such as natural angle of repose, solid friction, hardness, average speeds of grain movement over a flat swing screen. They also studied some aerodynamic properties of grains and straw such as drag coefficient, drag force, terminal velocity, Reynold's number and moisture of grain. They determined the terminal velocity of wheat, rice and barley. They found that the terminal velocity ranged from 5.85 to $9.71 \mathrm{~m} / \mathrm{s}$ for wheat varieties; from 7.89 to 8.55 $\mathrm{m} / \mathrm{s}$ for rice varieties; and 7.49 to $9.95 \mathrm{~m} / \mathrm{s}$ for barley varieties. Koide and Nishiyama (2001) measured the milling power and milling energy during abrasive milling under five rotor revolutions (800, 1000, 1400, $1600 \mathrm{rpm})$ using a batch type abrasive milling machine. Result indicated that the milling power decrease with milling time. Radwan (2001) showed that, the mechanical damage occurring in rice grains during the milling process depends not only on the milling machine design but also on the physical properties of rice. Experiments were conducted to study the milling quality and energy consumption for five local rice varieties (Giza-181, Giza-177 and Giza-178, Yasmien and Sakha-102) at different levels of moisture content. The experimental results showed that, grain variety and moisture content had profound effects on energy consumption and grain quality. Sotanabadi and 
Hemmat (2007) showed that excessive rotation of rice, when the grains revolve inside the milling chamber, increase breakage. Ease of grain movement in the milling chamber could minimize this problem by utilizing screw conveyor at the first part of rotor. In this study, the rotor of a conventional milling was equipped with a screw conveyor. The effects of two rotor types (modified and conventional rotors), three output rates of 412, 654 and $915 \mathrm{~kg} / \mathrm{h}$ and three blade distances from the agitator 11, 12 and 13 $\mathrm{mm}$ were examined on indices of rice quality. Results showed that only the effect of blade distance on percentage of breakage was significant and the effect of feed rate on all measured parameters was also significant. In addition, the interaction effects of rotor type and blade distance, rotor type and feed rate on percentage of whole white rice and breakage were significant, respectively. The milling performance index showed that the best conditions for both rotors can be obtained at output rate of $412 \mathrm{~kg} / \mathrm{h}$ and 11 or $12 \mathrm{~mm}$ blade distance from the agitator. For this adjustment the average of percentage of breakage in the modified and conventional rotors were 20.5 and 23, respectively. Varnamkhasti et al. (2007) stated that one of the methods in reducing the rice losses is to modify and optimize the current machines in the line of milling process. A rotor equipped with a screw conveyor was used. Factors were the rotor speed and the output flow rate for two common rice varieties. Results showed that the most effective factor on the quality of rice is the output flow rate in such a way that with its increase, an increase in the breakage percentage and a decrease in degree of milling was observed. The highest breakage percentage for both varieties occurred at $800 \mathrm{rpm}$ and output flow rate of $600 \mathrm{~kg} / \mathrm{h}$. Also, it was found that the Sazandegi variety showed higher breakage percentage and degree of milling in compare to those of Sorkheh variety. The highest and the lowest breakage percentages for both varieties occurred in the range of 400 to $600 \mathrm{~kg} / \mathrm{h}$. At last, for Sorkheh variety, a rotor speed of $600 \mathrm{rpm}$ with an output flow rate of 400 to $500 \mathrm{~kg} / \mathrm{h}$ and for the Sazandegi variety, a rotor speed of $700 \mathrm{rpm}$ and an output flow rate of $400 \mathrm{~kg} / \mathrm{h}$ were considered as the best combinations. Appiah, et al. (2011) estimated post harvest losses of rice from harvesting to milling to provide basic information important regarding the losses. They found that SB30 milling machine was more efficient and produced $67.3 \%$ 
head grains compared to SB10 (50\%) and the locally manufactured machine $47.3 \%$. So, the objectives of this study are to:

- Carry out mechanical analysis to determine sieve speed to be suitable for rice cleaning operation.

- Develop the rice milling machine by adding a cleaning unit and feeding auger to increase overall machine efficiency.

- Optimize some operating parameters (feed rate, drum speed and grain moisture content) affecting the performance of the rice milling machine.

- Evaluate the milling machine from the economic point of view.

\section{MATERIALS AND METHOD}

This study was carried out through the year of 2012 at Department of Agricultural Engineering, Faculty of Agriculture, Zagazig University to develop and evaluate the performance of a rice milling machine to improve product quality.

\subsection{MATERIALS:}

\subsubsection{The used crop:}

Three different rice varieties of (Sakha-105, Sakha-101 and Giza-171) were used. Some characteristics of rice grains were determined before milling operation such as: length, width, thickness, mass of 1000 grains, percent of sphericity and hardness.

\subsubsection{The rice milling machine before development:}

The machine consists mainly of power source, transmission system and frame. Milling unit (husking and whitening) is shown in Fig.1.

\subsubsection{The milling machine:}

The milling machine (abrasive type) was used to test the effect of operating parameters on milling yield of three rice varieties. Rice milling is the term of the combination of hulling and whitening processes. Hulling is the process to remove husk from paddy rice and whitening is the process to remove bran layer and germs from brown rice. The quality of milled rice samples was evaluated in terms of broken rice percentage and degree of whitening.

- The power source: The machine was powered by an electric motor 18.4 $\mathrm{kW}(25 \mathrm{hp})$ at a rated speed of $1500 \mathrm{rpm}$.

- The transmission system: The machine is operated by means of machine pulley (33.5 cm diameter) and belt powered from the electric motor pulley (19 $\mathrm{cm}$ diameter). The power is transmitted from the machine pulley to the 


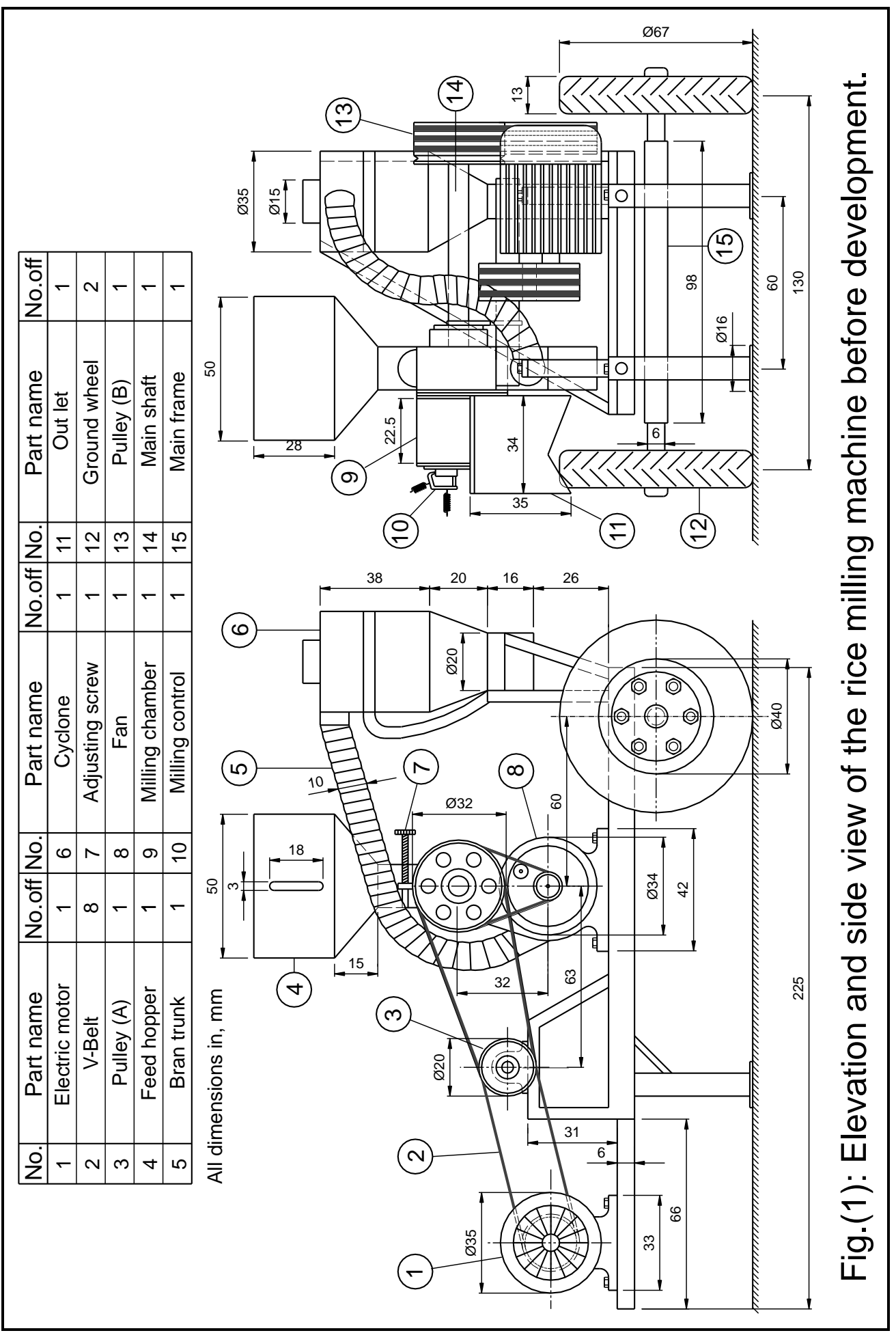


other moving parts by means of pulleys and belts with different speed ratios.

- The frame: is made of rectangular iron sheet steel. It includes elements to fix the motor, the transmission system, the husking and whitening unit. It was carried by two ground wheels of $76 \mathrm{~cm}$ diameter.

- The milling unit: consists of a drum and concave with holes. Specifications of the milling unit were as follows: type of milling is abrasive type, milling drum length $23 \mathrm{~cm}$, milling drum diameter $7.5 \mathrm{~cm}$, number of drum slices 2, concave length $25 \mathrm{~cm}$, concave cell shape rectangular having dimensions of (15-2 $\mathrm{mm})$.

\subsubsection{The rice milling machine after development:}

The rice milling machine was developed by supplying the original machine by two units: cleaning unit to be suitable for cleaning different rice varieties and feeding unit as shown in Fig.2. Such units were manufactured from low cost, local materials to increase overall machine efficiency comparing with the use of the other machines. The developed unit was manufactured specially for this work and constructed at a private workshop in Sharkia Governorate.

\section{A. The cleaning unit:}

The developed cleaning unit consists of a suction fan and two sieves (upper and lower). The specifications of a suction fan and sieves were as follows:

- Suction fan: has six blades with diameter of $450 \mathrm{~mm}$ and blade width of $140 \mathrm{~mm}$ producing air velocity about $6.5 \mathrm{~m} / \mathrm{s}$ to be less to the critical velocity of the grains of the three rice varieties (between 7.53 to $7.92 \mathrm{~m} / \mathrm{s}$ ) and in the same time more than the critical velocity if impurities (between 2.55 to $2.83 \mathrm{~m} / \mathrm{s}$ ). This fan was constructed to clean the rice from the chaff and other large materials.

- Upper sieve: consists of two sheets having dimensions (length and width) as follows: blanking sheet having dimensions of $(1000 \times 300 \mathrm{~mm})$ and perforated sheet with $8 \mathrm{~mm}$ cell diameter having dimensions of $(1000 \times 470$ $\mathrm{mm})$.

- Medium sieve: consists of four sheets having dimensions (length and width) as follows: front blanking sheet having dimensions of $(1000 \times 300$ $\mathrm{mm})$, perforated sheet with $4 \mathrm{~mm}$ cell diameter having dimensions of $(1000 \times 500 \mathrm{~mm})$, perforated sheet with $(25 \times 3 \mathrm{~mm})$ rectangular cells having 


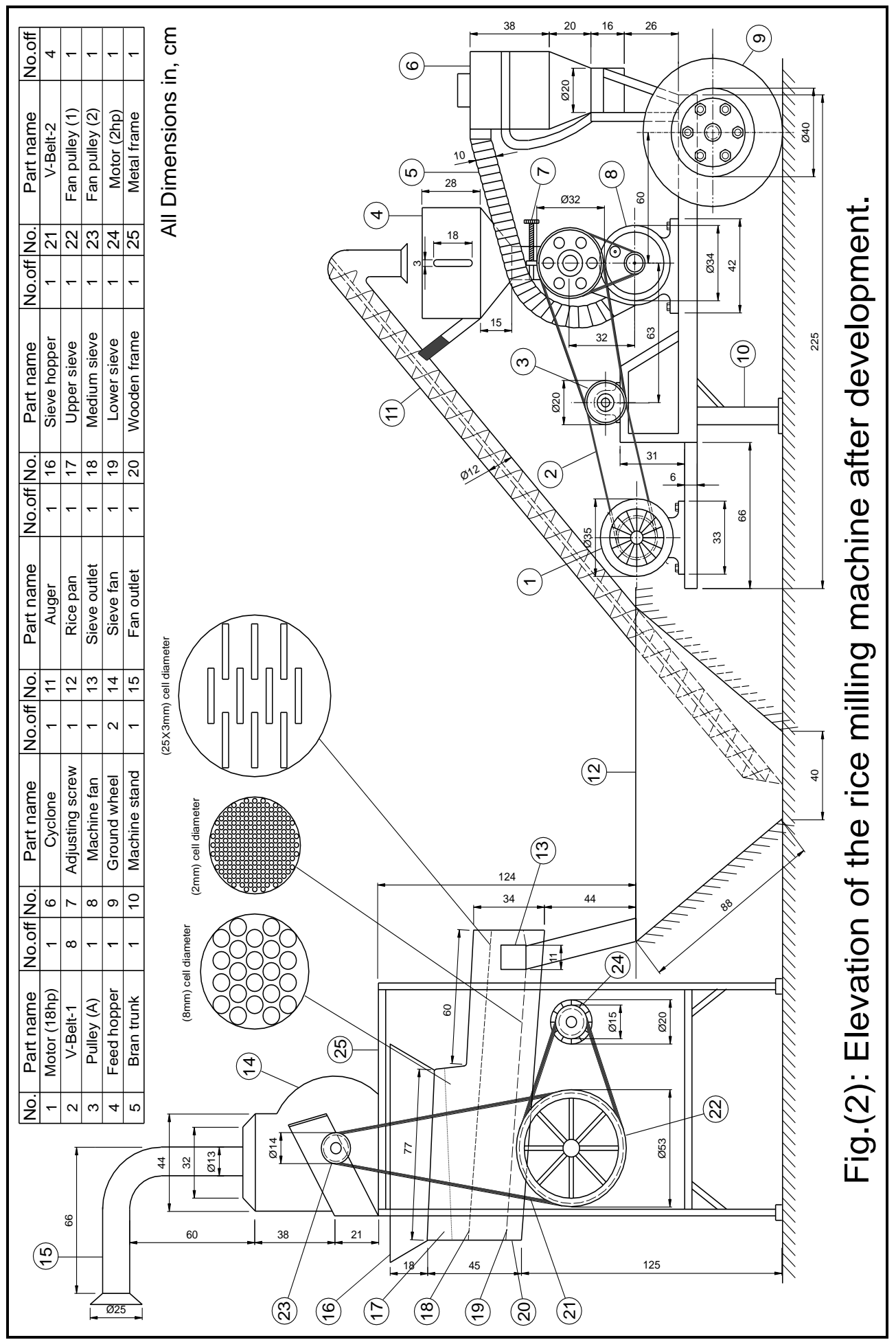


dimensions of $(1000 \times 600 \mathrm{~mm})$ and rear blanking sheet having dimensions of $(1000 \times 200 \mathrm{~mm})$.

- Lower sieve: consists of one perforated sheet with cell diameter of $2 \mathrm{~mm}$ having dimensions of $(1000 \times 1400 \mathrm{~mm})$.

\section{B. The feeding unit:}

The feeding unit consists of rice pan and feeding auger.

- Rice pan: It is trapezoidal in shape with dimensions of (1500 mm for the big base, $400 \mathrm{~mm}$ for the small base and $700 \mathrm{~mm}$ for the height). It was constructed above ground surface to receive the cleaning rice from the cleaning unit.

- Feeding auger: A locally manufactured feeding auger was constructed between the rice pan and milling machine feed hopper to transfer the cleaning rice from the rice pan to the milling machine with adjustable feed rate.

\subsection{METHOD:}

The samples were taken after they harvested by the combine at grain moisture content of about $21.2 \%$. Then, they dried using natural drying method under shade with in layers, to get the different levels of grain moisture content in order to study their effect on total grain losses and overall machine efficiency at different operating parameters using the developed milling machine.

\subsubsection{Physical and engineering properties of rice varieties:}

Physical and engineering properties of grains under study have to be considered to study their effect on the performance of the milling machine. A random sample of about 500 grains was taken from each variety to determine some physical properties such as: length, width, thickness, mass of 1000 grains and percent of sphericity; and some engineering properties (aerodynamic and mechanical properties) such as: terminal velocity, dynamic head, repose angle and friction angle. A grain dimension was measured using the digital vernire caliper in each rice variety.

\subsubsection{Sieve speed adjustment:}

A vibrated sieve is used to remove impurities adhering to seeds. Agitation of the separating sieve results in displacement of the grains over its surface. The grains should be so agitated that separation is optimal. The seeds should be uniformly distributed over the sieve surface and moved towards the delivery 
end of the sieve. The sieve is agitated by multiple system linkage kinematics characteristics of linear motion of the driving link and the crank-connecting rod mechanism for small values of $\mathrm{r} / \mathrm{L}$ (crank shaft length/connecting rod length) are given by the following (Klenin et al., 1985):

$$
\chi=r(1-\cos \omega t) \quad \& \quad \dot{\chi}=\omega r \sin \omega t \quad \& \quad \ddot{\chi}=w^{2} r \cos \omega t
$$

Where:

$$
\begin{gathered}
\chi: \text { Instantaneous displacement, } \mathrm{cm} \quad \dot{\chi}: \text { Motion velocity, } \mathrm{cm} / \mathrm{s} \\
\ddot{\chi}: \text { Acceleration of motion, } \mathrm{cm} / \mathrm{s}^{2} \quad \omega: \text { Angular velocity, } \mathrm{rad} / \mathrm{s} \\
\text { r: Crank shaft length, } \mathrm{cm}
\end{gathered}
$$

\section{- Forces acting grain lying on a sieve:}

W: Force due to the weight of the seed directed downward.

Fi: Inertia force acting in a direction opposite to that of the mass acceleration force. The magnitude of the force $\mathbf{F i}$ is obtained from the expression:

$$
\mathrm{Fi}=\mathrm{m} \ddot{\chi}=\mathrm{m} \omega^{2} \mathrm{r} \cos \omega \mathrm{t}
$$

Ff: Friction force between the seed and the sieve surface acting in a direction opposite to that of the direction of relative motion.

R: Reaction force of the working surface on the seed acting in a direction normal to the surface.

The sieve is set horizontal or inclined to the horizontal plane, the angle of inclination selected from the condition.

$$
\alpha \leq \varphi
$$

Where:

$\mathrm{m}$ : The mass of seed, $\mathrm{kg}$.

$\alpha$ : Angle of sieve with the horizontal.

$\varphi$ : The friction angle between the grains and the sieve surface $(\varphi=45$ deg).

According to the condition given above, the material will not slide over the sieve when it is stationary. When the sieve is agitated at a particular frequency and amplitude, a motion is imported to the grains relative to the sieve surface. The possible types of motion of the grains are only sliding motion over the sieve towards the delivery end, and in the reverse direction or loss of all contact between the grains and the sieve surface. 
- Motion of grains over the sieve at the delivery end from A to B:

Motion at the delivery end is possible when the resultant of all forces acting the grain is greater than the friction force, Fig. 3 that is:

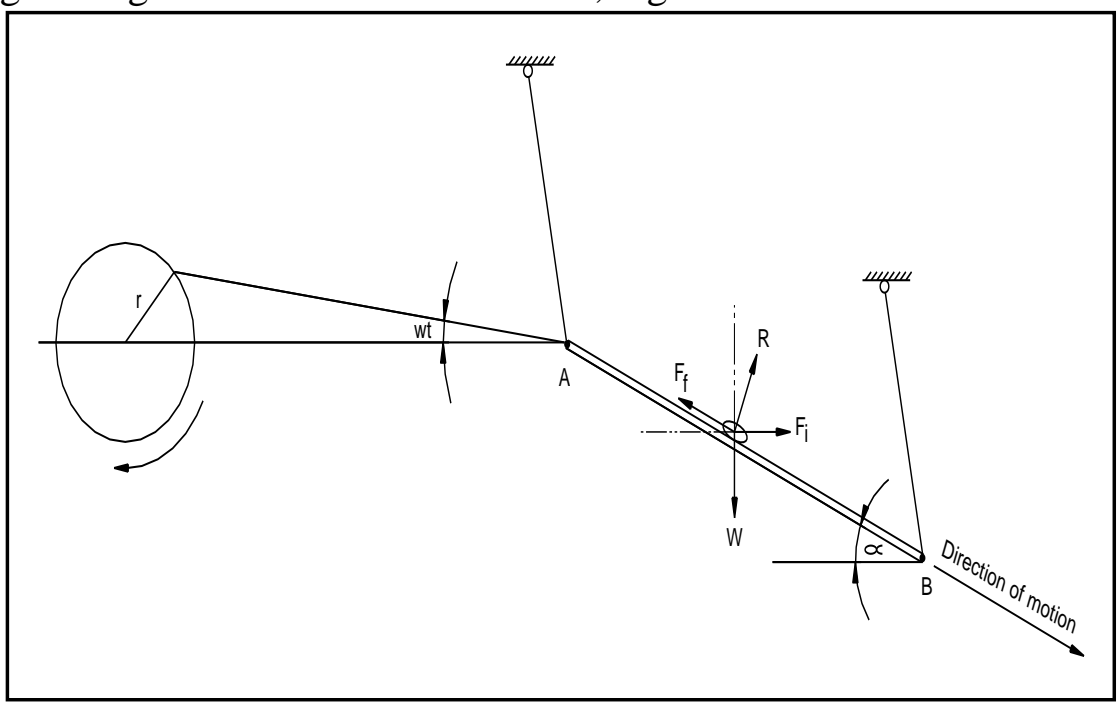

Fig. 3. Motion of grain over the sieve at the delivery end (from $A$ to $B$ ).

$$
\begin{gathered}
\omega \sin \alpha+F i \cos \alpha \geq \text { Ff } \\
\text { Ff }=R \tan \varphi=\mu \mathrm{R}
\end{gathered}
$$

Where:

Ff : The friction force.

$$
\varphi \text { : Friction angle. }
$$
$\mu$ : Coefficient of friction.
$\mathrm{R}$ : Normal force.

To determine force $(\mathrm{R})$ projecting all the force in a direction normal to the sieve.

$$
\mathrm{R}=\omega \cos \alpha-\mathrm{Fi} \sin \alpha
$$

Then motion of the grains at the exit may be expressed by the following inequality:

$$
\omega \sin \alpha+F i \cos \alpha \geq \mu \omega \cos \alpha-\mu \text { Fi } \sin \alpha
$$

or

$$
\begin{array}{r}
\mathrm{mg} \sin \alpha+\mathrm{m} \omega^{2} \mathrm{r} \cos \alpha \geq \mu \mathrm{mg} \cos \alpha-\mu \mathrm{m} \omega \\
\omega_{1}=\sqrt{\frac{\mathrm{g}(\mu \cos \alpha-\sin \alpha)}{\mathrm{r}(\cos \alpha+\mu \sin \alpha)}}, \mathrm{rad} / \mathrm{s} \\
\mathrm{N}_{1}=\frac{60}{2 \pi} \sqrt{\frac{\mathrm{g}(\mu \cos \alpha-\sin \alpha)}{\mathrm{r}(\cos \alpha+\mu \sin \alpha)}}, \mathrm{rpm}
\end{array}
$$


- Sliding motion of the grain up and down the surface from B to A.

Fig. 4 shows the movement of grains from $\mathrm{B}$ to $\mathrm{A}$ is possible when:

Fi $\cos \alpha-\omega \sin \alpha \geq$ Ff

Where:

$\mathrm{R}=\omega \cos \alpha+\mathrm{Fi} \sin \alpha$

Then the motion of the grain in this case may be expressed by the following inequality:

Fi $\cos \alpha-\omega \sin \alpha \geq \mu \omega \cos \alpha+\mu$ Fi $\sin \alpha$

$\mathrm{m} \omega^{2} \mathrm{r} \cos \alpha-\mathrm{mg} \sin \alpha \geq \mu \mathrm{mg} \cos \alpha+\mu \mathrm{m} \omega^{2} \mathrm{r} \sin \alpha$

$$
\begin{aligned}
\omega_{2} & =\sqrt{\frac{\mathrm{g}(\mu \cos \alpha+\sin \alpha)}{\mathrm{r}(\cos \alpha-\mu \sin \alpha)}}, \mathrm{rad} / \mathrm{s} \\
\text { or }_{2} & =\frac{60}{2 \pi} \sqrt{\frac{\mathrm{g}(\mu \cos \alpha+\sin \alpha)}{\mathrm{r}(\cos \alpha-\mu \sin \alpha)]}}, \mathrm{rpm}
\end{aligned}
$$

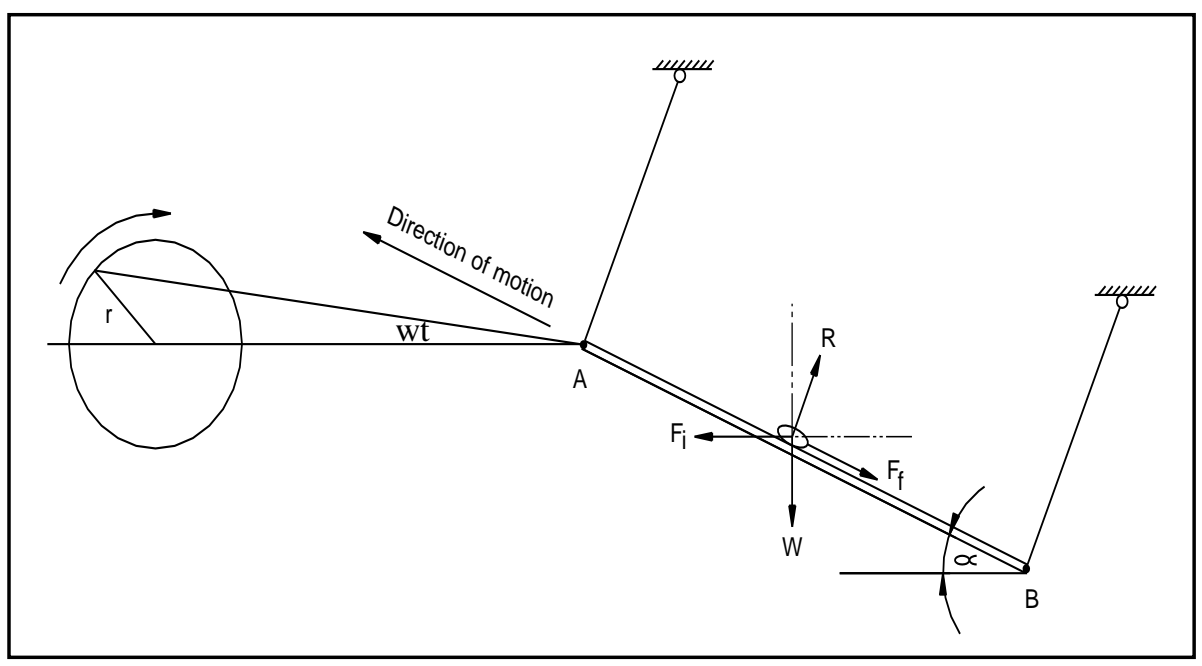

Fig. 4. Motion of grain over the sieve at the delivery end (from B to A).

- Riding of grains on the sieve surface:

The motion of grains in this case may be expressed by the following in equality:

$$
\omega \sin \alpha+F i \cos \alpha \geq F f
$$

But in this case $\mathrm{R}=0 \quad \therefore \mathrm{Ff}=0$

$$
\text { Fi } \cos \alpha \geq-\omega \sin \alpha
$$




$$
\omega_{3}=\sqrt{\frac{-\mathrm{g} \sin \alpha}{\mathrm{r} \cos \alpha}}, \mathrm{rad} / \mathrm{s} \quad \text { or } \quad \mathrm{N}_{3}=\frac{60}{2 \pi} \sqrt{\frac{-\mathrm{g} \sin \alpha}{\mathrm{r} \cos \alpha}}, \mathrm{rpm}
$$

It follows from these equations that the mass of seeds and impurities moves along the sieve both toward the exit $\left(\mathrm{N}>\mathrm{N}_{1}\right)$ and to the opposite direction ( $\mathrm{N}$ $>\mathrm{N}_{2}$ ). Sieving and separating impurities from seeds are more successful under the following conditions:

$$
\mathrm{N}_{3}>\mathrm{N}>\mathrm{N}_{2} \text { and } \mathrm{N}_{2}>\mathrm{N}_{1}
$$

Where:

$\mathrm{N}$ : The optimum sieve speed. $\alpha=14$ deg for the three used varieties.

(to be less than the friction angle between the seeds and the sieve surface).

Under the above conditions and by using the previous equations, optimum sieve speed was calculated to be as follows:

$\mathrm{N}=400 \mathrm{rpm}$, for the three used rice varieties.

\subsubsection{Experimental conditions:}

The performance of the developed milling machine was experimentally measured under the following parameters: Three rice varieties of Sakha-105, Sakha-101 and Giza-171; four different feed rates of 1.2, 1.4, 1.6, and 1.8 $\mathrm{Mg} / \mathrm{h}$; four different drum speeds $750,800,850$, and $950 \mathrm{rpm}$ and four different grain moisture contents of $13,14,15$, and $16 \%$ in average.

\subsection{MEASUREMENTS AND DETERMINATIONS:}

Evaluation of the performance of the developed rice milling machine was based on the following indicators:

\section{- Total grain losses:}

Total grain losses includes both unshelled grain losses and broken grain losses. The percentage of total losses was calculated using the following equation:

Totalgrain losses $=$ unshelled grain losses + broken grain losses

\section{- The percentage of unshelled grains $\left(\right.$ unsh $\left._{\mathrm{g}}\right)$ :}

$$
\text { unsh }_{\mathrm{g}}=\frac{\text { Mass of unshulled rice grains of thesample }}{\text { Totalmass of thesample }} \times 100
$$

- The percentage of broken grains $(\mathrm{Bg})$ :

$$
\mathrm{Bg}=\frac{\text { Mass of broken rice grains of thesample }}{\text { Totalmass of thesample }} \times 100
$$




\section{- Overall machine efficiency:}

Overall machine efficiency was calculated using the following equation:

$$
\mathrm{Me}=\frac{\text { Output grain mass frommilling operationof thesample }}{\text { Totalmass of thesample }} \times 100
$$

\section{- Machine productivity:}

Machine productivity was determined by the following equation:

$$
\mathrm{Mp}=\frac{\mathrm{Ms}}{\mathrm{t}}, \mathrm{kg} / \mathrm{h}
$$

Where:

$\mathrm{Mp}=$ machine productivity, $\mathrm{kg} / \mathrm{h}$.

$\mathrm{Ms}=$ mass of sample, $\mathrm{kg}$.

$\mathrm{t}=$ time consumed in the milling operation, $\mathrm{h}$.

\section{- Required power:}

The following formula was used to estimate the required power.

$$
\mathrm{P}=\sqrt{3} \times \cos \varphi \times \mathrm{I} \times \mathrm{V}
$$

Where:

$\mathrm{P}=$ power required, $\mathrm{kW} \quad \mathrm{I}=$ current intensity, Ampere

$\mathrm{V}=$ Voltage, $(380 \mathrm{~V}) \quad \cos \varphi=0.70$

\section{- Specific energy:}

Specific energy for the threshing and cleaning operation can be calculated as follows:

$$
\text { Specific energy }=\frac{\text { Motorpower }}{\text { Machine productivity }}, \mathrm{kW} \cdot \mathrm{h} / \mathrm{Mg}
$$

\section{- Criterion cost:}

The criterion cost required for the threshing and cleaning operation was estimated using the following equation (Awady, 1982):

Criterioncost $=$ operatingcost + grain losses cost, $\mathrm{L} . \mathrm{E} . / \mathrm{Mg}$

$$
\text { Operatingcost }=\frac{\text { Machine cost }}{\text { Machine productivity }}, \mathrm{L} \cdot \mathrm{E} / \mathrm{Mg}
$$

The machine cost was determined by using the following equation (Awady, 1982):

$$
\mathrm{C}=\frac{\mathrm{p}}{\mathrm{h}}\left(\frac{1}{\mathrm{a}}+\frac{\mathrm{i}}{2}+\mathrm{t}+\mathrm{r}\right)+(\mathrm{W} \cdot \mathrm{e})+\frac{\mathrm{m}}{144}
$$

Where: 
$\mathrm{C}=$ machine cost, L.E./h.

$\mathrm{h}=$ yearly working hours, $\mathrm{h} /$ year.

$\mathrm{i}=$ interest rate/year.

$\mathrm{r}=$ repairs and maintenance ratio.

$\mathrm{e}=$ hourly cost $/ \mathrm{kW} \cdot \mathrm{h}$. $\mathrm{p}=$ price of machine, L.E.

$\mathrm{a}=$ life expectancy of the machine, $\mathrm{h}$.

$\mathrm{t}=$ taxes, over heads ratio.

$\mathrm{W}=$ power of motor in $\mathrm{kW}$.

$\mathrm{m}=$ the monthly average wage, L.E.

$144=$ reasonable estimation of monthly working hours.

\section{RESULTS AND DISCUSSION}

From the theoretical study as mentioned in materials and method chapter and also from the pre experiments, the optimum fan velocity, sieve speed and sieve inclination were determined and adjusted at $6.5 \mathrm{~m} / \mathrm{s}, 400 \mathrm{rpm}$ and 4 deg, respectively to be suitable for operating the cleaning unit attached with the rice milling machine to maximize its efficiency and rice quality.

The obtained results will be discussed under the following items:

\subsection{Physical and engineering properties of rice grains:}

Table 1 shows some physical properties of the rice grains while Table 2 shows some engineering properties of the same grains.

Table 1. Some physical properties of rice grains.

\begin{tabular}{|c|c|c|c|c|c|c|c|c|c|c|}
\hline \multirow[b]{2}{*}{ 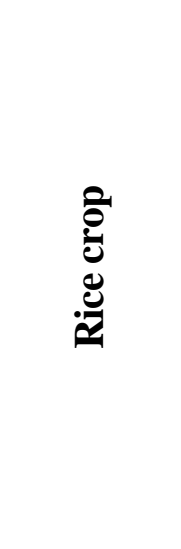 } & \multicolumn{10}{|c|}{ Physical properties } \\
\hline & 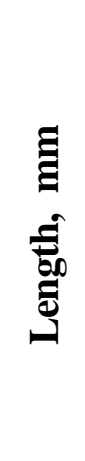 & 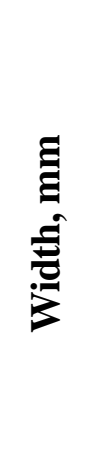 & 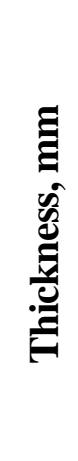 & 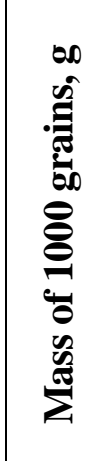 & $\begin{array}{l}\stackrel{m}{\Xi} \\
\stackrel{\Xi}{\Xi} \\
\stackrel{\Xi}{\Xi}\end{array}$ & 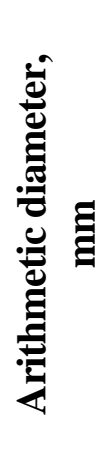 & 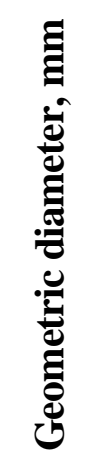 & 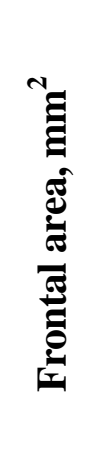 & 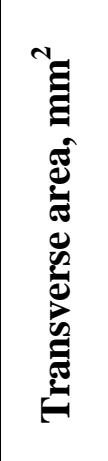 & 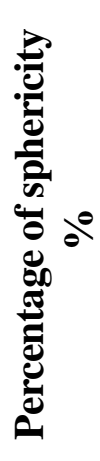 \\
\hline Sakha-101 & 7.93 & 3.24 & 2.09 & 23.80 & 28.10 & 4.42 & 3.77 & 20.17 & 46.01 & 47.58 \\
\hline Giza-171 & 7.83 & 2.91 & 2.04 & 21.90 & 24.33 & 4.26 & 3.60 & 17.89 & 42.74 & 45.92 \\
\hline Sakha-105 & 7.76 & 2.91 & 2.01 & 26.80 & 23.75 & 4.23 & 3.57 & 17.73 & 42.07 & 45.97 \\
\hline
\end{tabular}


Table 2. Some engineering properties of the used rice varieties.

\begin{tabular}{||c|c|c|c|c||}
\hline \multirow{4}{*}{ Rice crop } & \multicolumn{4}{|c||}{ Engineering properties } \\
\cline { 2 - 5 } & \multicolumn{2}{|c|}{ Aerodynamic properties } & \multicolumn{2}{c||}{ Mechanical properties } \\
\cline { 2 - 5 } & $\begin{array}{c}\text { Critical velocity } \\
\text { of grains, } \\
\mathbf{~ m / s}\end{array}$ & $\begin{array}{c}\text { Impurities } \\
\text { critical velocity, } \\
\mathbf{m} / \mathbf{s}\end{array}$ & $\begin{array}{c}\text { Repose angle, } \\
\mathbf{d e g} .\end{array}$ & $\begin{array}{c}\text { Friction angle, } \\
\mathbf{d e g} .\end{array}$ \\
\hline Sakha-101 & $7.70-7.76$ & $2.64-2.72$ & $30-33$ & $35-38$ \\
\hline Giza-171 & $7.53-7.57$ & $2.55-2.61$ & $33-37$ & $38-41$ \\
\hline Sakha-105 & $7.84-7.92$ & $2.79-2.83$ & $35-39$ & $40-44$ \\
\hline
\end{tabular}

\subsection{Effect of some operating parameters on total grain losses at different rice varieties:}

Representative values of unshelled grains, broken grains and total grains losses versus feed rate, drum speed and grain moisture content at different rice varieties are given in Fig.5. Concerning to the effect of feed rate on the total grain losses, increasing feed rate from 1.2 to $1.4 \mathrm{Mg} / \mathrm{h}$, the total grain losses decreased from 5.26 to $5.00 \%$ for Sakha-101 variety. Any further increase in feed rate more than 1.4 up to $1.8 \mathrm{Mg} / \mathrm{h}$ increased total grain losses from 5.00 to $5.80 \%$ at constant drum speed of $800 \mathrm{rpm}$ and grain moisture content of $14 \%$. While, for the other rice verities of Giza-171 and Sakha105 , increasing feed rate from 1.2 to $1.6 \mathrm{Mg} / \mathrm{h}$, the total grain losses decreased from 4.88 to $4.62 \%$ and from 4.59 to $4.34 \%$, respectively. Any further increase in feed rate more than 1.6 up to $1.8 \mathrm{Mg} / \mathrm{h}$ the total grain losses increased from 4.62 to $5.10 \%$ and from 4.34 to $4.75 \%$ with the same rice varieties at constant drum speed of $850 \mathrm{rpm}$, grain moisture content of $15 \%$. Increasing feed rate led to increase unshelled grains due the excessive grains in the milling unit, consequently the material leave the device without adequate milling that tends to increase unshelled grains. So, the total grain losses including both broken grains and unshelled grains are essential to establish optimum working conditions. 

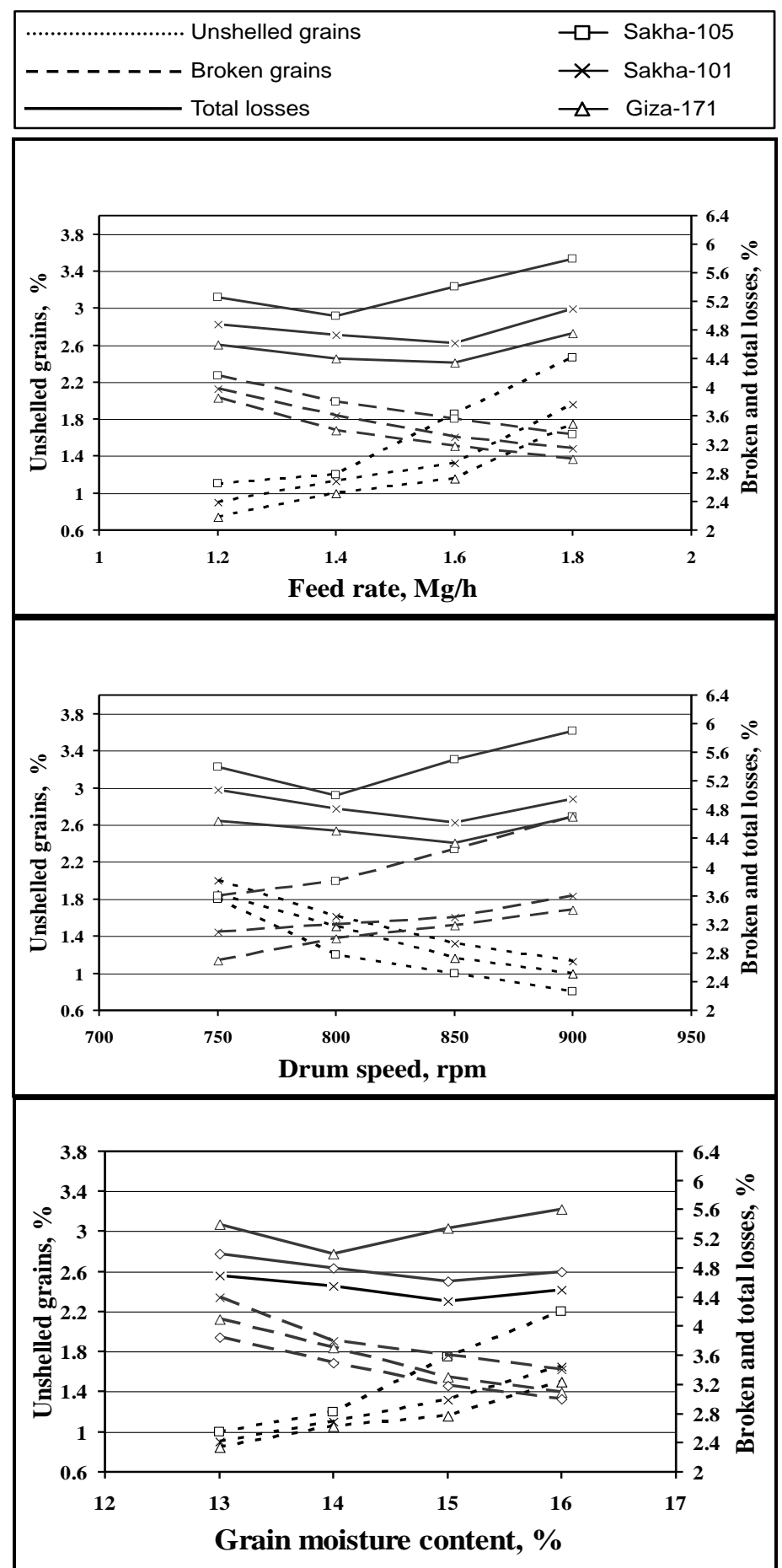

Fig.5. Effect of some operating parameters on the unshelled, broken and total grain losses at different rice varieties. 
Relating to the effect of drum speed on the total grain losses, Fig.5 shows that, increasing drum speed from 750 to $800 \mathrm{rpm}$ the total grain losses decreased from 5.40 to $5.00 \%$ for Sakha-101 variety. Any further increase in drum speed more than 800 up to $900 \mathrm{rpm}$ increased total grain losses from 5.00 to $5.90 \%$ at constant feed rate of $1.4 \mathrm{Mg} / \mathrm{h}$ and grain moisture content of $14 \%$. While, for the other rice verities of Giza-171 and Sakha-105, increasing drum speed from 750 to $850 \mathrm{rpm}$, the total grain losses decreased from 5.00 to $4.62 \%$ and from 4.55 to $4.34 \%$, respectively. Any further increase in drum speed more than 850 up to $900 \mathrm{Mg} / \mathrm{h}$ the total grain losses increased from 4.62 to $4.95 \%$ and from 4.34 to $4.70 \%$ with the same rice varieties at constant feed rate of $1.6 \mathrm{Mg} / \mathrm{h}$ and grain moisture content of 15 $\%$. The increase in broken grains by increasing drum speed is due to the high impacting force applied to the grains by the drum slices. While the decrease in unshelled grains by increasing drum speed is attributed to the high stripping and impacting forces applied to the grains, that tended to improve milling operation and decrease unshelled grains.

With respect to the effect of grain moisture content on the total grain losses, results in Fig.5 show that, increasing grain moisture content from 13 to $14 \%$ the total grain losses decreased from 5.40 to $5.00 \%$ for Sakha-101 variety. Any further increase in grain moisture content more than 14 up to $16 \%$ increased total grain losses from 5.00 to $5.60 \%$ at constant drum speed of $800 \mathrm{rpm}$ and feed rate of $1.4 \mathrm{Mg} / \mathrm{h}$. While, for the other rice verities of Giza171 and Sakha-105, increasing grain moisture content from 13 to $15 \%$, the total grain losses decreased from 5.00 to $4.62 \%$ and from 4.70 to $4.34 \%$, respectively. Any further increase in grain moisture content more than 15 up to $16 \%$ the total grain losses increased from 4.62 to $4.75 \%$ and from 4.34 to $4.50 \%$ with the same rice varieties at constant drum speed of $850 \mathrm{rpm}$ and feed rate of $1.6 \mathrm{Mg} / \mathrm{h}$. Higher values of grain moisture content more than the optimum value tend to increase the total losses because of increasing unshelled grains by increasing grain moisture content. On the other side, the lower values of grain moisture content less than the optimum value tend to increase total grain losses due to the increase in broken grains by decreasing grain moisture content.

3.3. Effect of some operating parameters on overall machine efficiency and its productivity at different rice varieties:

Representative values of both machine productivity and overall machine efficiency versus feed rate, drum speed and grain moisture content at different rice varieties are given in Fig.6. 


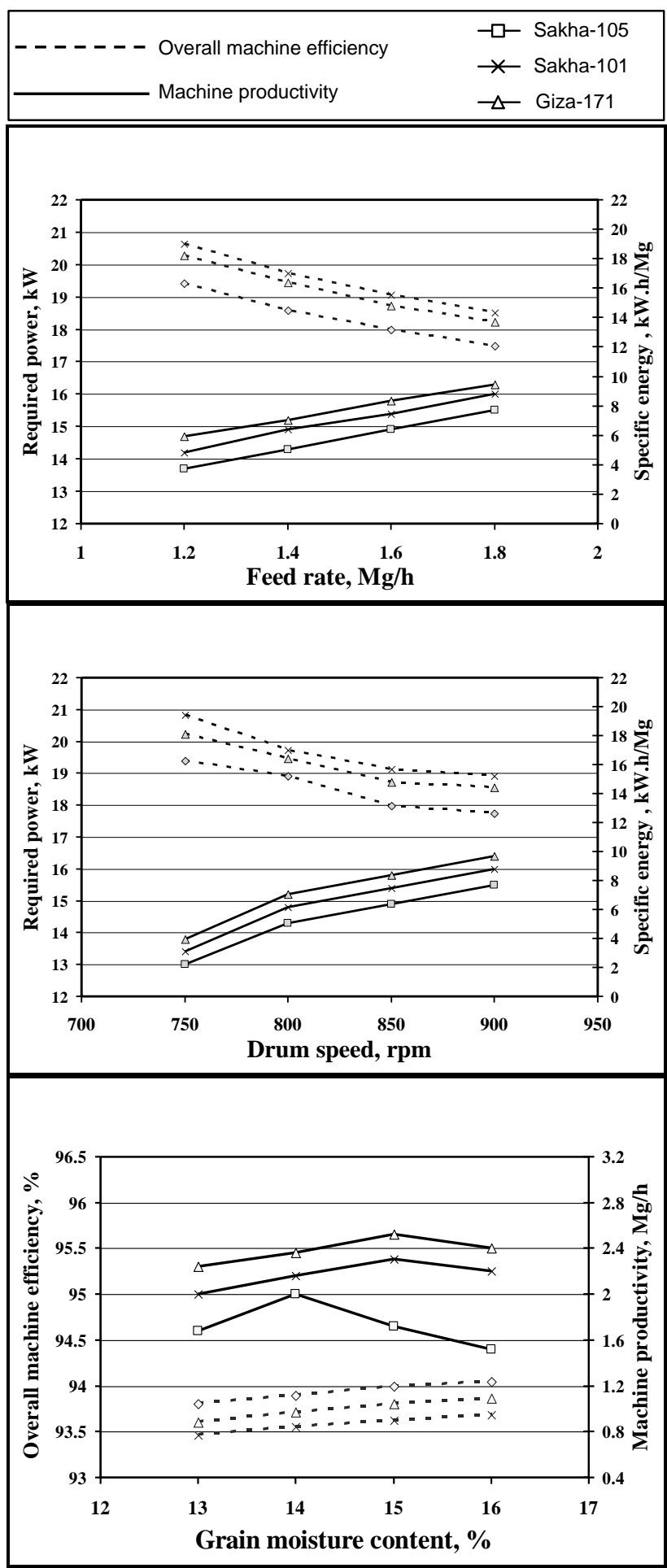

Fig.6. Effect of some operating parameters on overall machine efficiency and its productivity at different rice varieties.

Misr J. Ag. Eng., July 2013 
Concerning to the effect of feed rate on overall machine efficiency, increasing feed rate from 1.2 to $1.4 \mathrm{Mg} / \mathrm{h}$ the overall machine efficiency increased from 94.74 to $95.00 \%$, for Sakha-101 variety. Any further increase in feed rate more than 1.4 up to $1.8 \mathrm{Mg} / \mathrm{h}$ decreased overall machine efficiency from 95.00 to $94.20 \%$ at constant drum speed of $800 \mathrm{rpm}$ and grain moisture content of $14 \%$. While, for the other rice verities of Giza-171 and Sakha-105, increasing feed rate from 1.2 to $1.6 \mathrm{Mg} / \mathrm{h}$ the overall machine efficiency increased from 95.12 to $95.38 \%$ and from 95.41 to 95.66 $\%$, respectively. Any further increase in feed rate more than 1.6 up to 1.8 $\mathrm{Mg} / \mathrm{h}$ the overall machine efficiency decreased from 95.38 to $94.90 \%$ and from 95.66 to $95.25 \%$ with the same rice varieties at constant drum speed of $850 \mathrm{rpm}$, grain moisture content of $15 \%$. Relating to the effect of feed rate on the machine productivity, Fig.6 show that, increasing feed rate from 1.2 to $1.8 \mathrm{Mg} / \mathrm{h}$ the machine productivity increased from 0.72 to 0.81 , from 0.78 to 1.17 and 0.9 to $1.35 \mathrm{Mg} / \mathrm{h}$ for Sakha-101, Giza-171 and Sakha-105, respectively, at the same previous conditions.

Regarding to the effect of drum speed on overall machine efficiency, increasing drum speed from 750 to $800 \mathrm{rpm}$ the overall machine efficiency increased from 94.60 to $95.00 \%$, for Sakha-101 variety. Any further increase in drum speed more than 800 up to $900 \mathrm{rpm}$ decreased overall machine efficiency from 95.00 to $94.10 \%$ at constant feed rate of $1.4 \mathrm{Mg} / \mathrm{h}$ and grain moisture content of $14 \%$. While, for the other rice verities of Giza-171 and Sakha-105, increasing drum speed from 750 to $850 \mathrm{rpm}$ the overall machine efficiency increased from 95.00 to $95.38 \%$ and from 95.45 to $95.66 \%$, respectively.

Any further increase in drum speed more than 850 up to $900 \mathrm{rpm}$ the overall machine efficiency decreased from 95.38 to $95.05 \%$ and from 95.66 to $95.30 \%$ with the same rice varieties at constant feed rate of $1.6 \mathrm{Mg} / \mathrm{h}$, grain moisture content of $15 \%$. Relating to the effect of drum speed on the machine productivity, Fig.6 show that, increasing drum speed from 750 to $900 \mathrm{rpm}$ the machine productivity increased from 0.67 to 1.02 , from 0.74 to 1.11 and 0.85 to $1.30 \mathrm{Mg} / \mathrm{h}$ for Sakha-101, Giza-171 and Sakha-105, respectively, at the same previous conditions. The increase in overall machine efficiency in the range from 750 to $850 \mathrm{rpm}$ is attributed to the high stripping and impacting forces applied to the grains, that tend to improve milling operation. While the vise versa is noticed in the range from 850 to $900 \mathrm{rpm}$ due to the increase in grain losses. 
Concerning to the effect of grain moisture content on overall machine efficiency, increasing grain moisture content from 13 to $14 \%$ the overall machine efficiency increased from 94.60 to $95.00 \%$, for Sakha-101 variety. Any further increase in feed rate more than 14 up to $16 \%$ decreased overall machine efficiency from 95.00 to $94.40 \%$ at constant drum speed of 800 $\mathrm{rpm}$ and feed rate of $1.4 \mathrm{Mg} / \mathrm{h}$. While, for the other rice verities of Giza-171 and Sakha-105, increasing grain moisture content from 13 to $15 \%$ the overall machine efficiency increased from 95.00 to $95.38 \%$ and from 95.30 to $95.66 \%$, respectively. Any further increase in grain moisture content more than 15 up to $16 \%$ the overall machine efficiency decreased from 95.38 to $95.25 \%$ and from 95.66 to $95.50 \%$ with the same rice varieties at constant drum speed of $850 \mathrm{rpm}$, feed rate of $1.6 \mathrm{Mg} / \mathrm{h}$. Relating to the effect of feed rate on the machine productivity, Fig. 6 show that, increasing grain moisture content from 13 to $16 \%$ the machine productivity increased from 0.77 to 0.95 , from 0.88 to 1.09 and 1.04 to $1.24 \mathrm{Mg} / \mathrm{h}$ for Sakha-101, Giza-171 and Sakha-105, respectively, at the same previous conditions. Values of grain moisture content more than or less to the optimum value tend to decrease machine efficiency because of increasing the total grain losses. With respect to the machine productivity increased by increasing grain moisture content due to the increase in weight of grains.

\subsection{Effect of some operating parameters on required power and specific} energy at different rice varieties:

Values of both required power and specific energy versus feed rate, drum speed and grain moisture content at different rice varieties are given in Fig.7. Relating to the effect of feed rate on required power and specific energy, increasing feed rate from 1.2 to $1.8 \mathrm{Mg} / \mathrm{h}$, the required power increased from 13.70 to $15.50 \mathrm{~kW}$, while the specific energy decreased from 19.03 to 14.35 $\mathrm{kW} . \mathrm{h} / \mathrm{Mg}$, for Sakha-101 variety, at constant drum speed $800 \mathrm{rpm}$ and grain moisture content of $14 \%$. For the other rice verities of Giza-171 and Sakha105 , increasing feed rate from 1.2 to $1.8 \mathrm{Mg} / \mathrm{h}$ the required power increased from 14.20 to 16.00 and from 14.70 to $16.30 \mathrm{~kW}$, while the specific energy decreased from 18.21 to 13.68 and from 16.33 to $12.07 \mathrm{~kW} . \mathrm{h} / \mathrm{Mg}$, for Giza171 and Sakha-105, respectively, at constant drum speed $850 \mathrm{rpm}$ and grain moisture content of $15 \%$. 


\begin{tabular}{|ll|}
\hline- Power requirements & $-\square-$ Sakha-105 \\
$--\ldots-\ldots-\ldots$ - Consumed energy & $\rightarrow-$ Sakha-101 \\
& $-\triangle$ Giza-171 \\
\hline
\end{tabular}
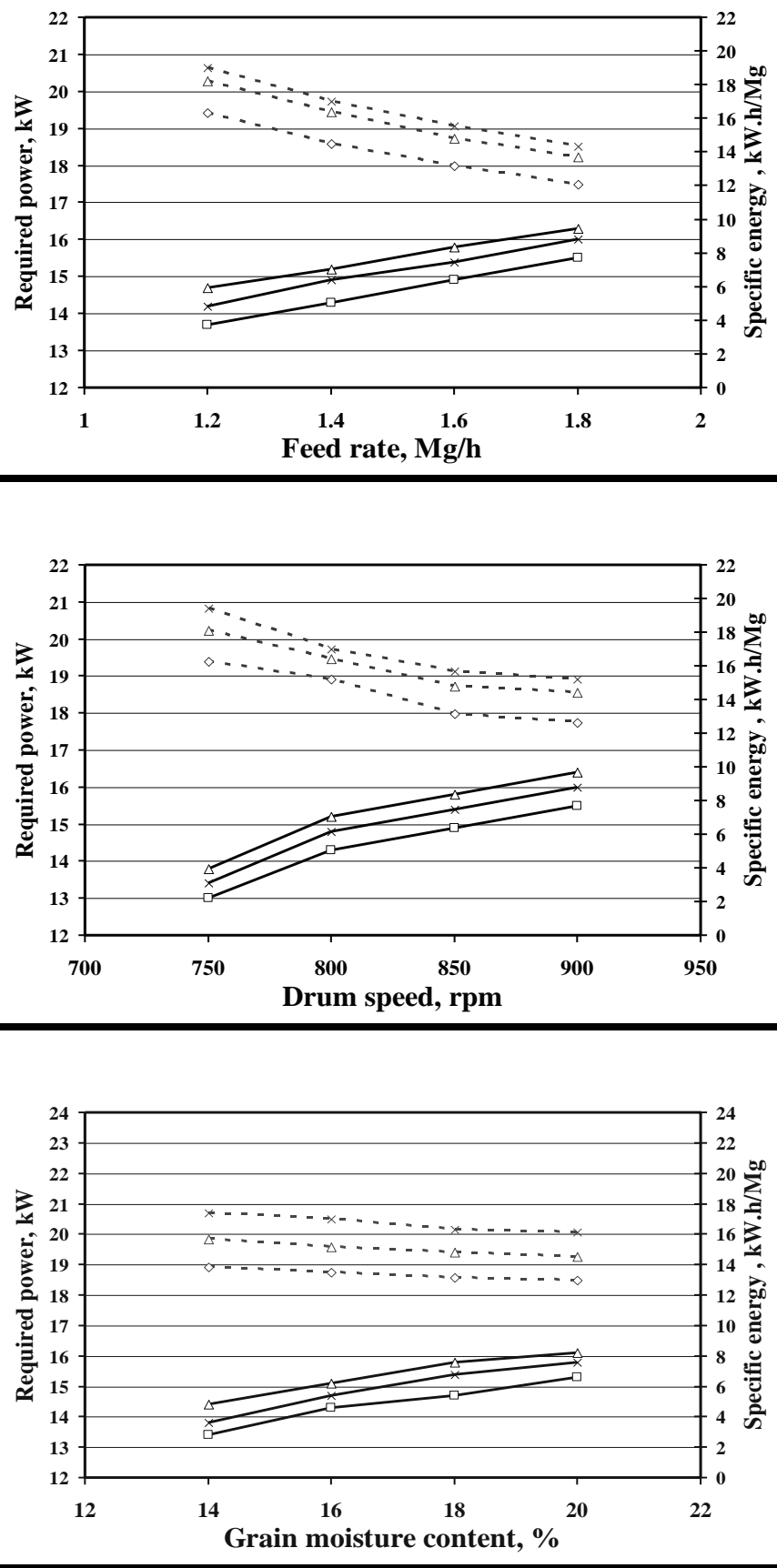

Fig.7. Effect of some operating parameters on required power and specific energy at different rice varieties.

Misr J. Ag. Eng., July 2013 
As to the effect of drum speed on required power and specific energy, increasing drum speed from 750 to $900 \mathrm{rpm}$, the required power increased from 13.00 to $15.50 \mathrm{~kW}$, while the specific energy decreased from 19.40 to15.20 kW.h/Mg, for Sakha-101 variety, at constant feed rate of $1.4 \mathrm{Mg} / \mathrm{h}$ and grain moisture content of $14 \%$. For the other rice verities of Giza-171 and Sakha-105, increasing drum speed from 750 to $900 \mathrm{rpm}$ the required power increased from 13.40 to 16.00 and from 13.80 to $16.40 \mathrm{~kW}$, while the specific energy decreased from 18.11 to 14.41 and from 16.24 to 12.62 $\mathrm{kW} . \mathrm{h} / \mathrm{Mg}$, for Giza-171 and Sakha-105, respectively, at constant feed rate of $1.6 \mathrm{Mg} / \mathrm{h}$ and grain moisture content of $15 \%$. Power and specific energy increased by increasing drum speed mainly because the increase in drum speed is frequently accompanied by appreciable increase in electric consumption, that tends to increase power and energy.

In relation to the effect of grain moisture content on required power and specific energy, obtained results show that increasing grain moisture content from 13 to $16 \%$, the required power increased from 13.40 to $15.30 \mathrm{~kW}$, while the specific energy decreased from 17.40 to $16.11 \mathrm{~kW} . \mathrm{h} / \mathrm{Mg}$, for Sakha101 variety, at constant drum speed of $800 \mathrm{rpm}$ and feed rate of $1.4 \mathrm{Mg} / \mathrm{h}$. For the other rice verities of Giza-171 and Sakha-105, increasing grain moisture content from 13 to $16 \%$ the required power increased from 13.80 to 15.80 and from 14.40 to $16.10 \mathrm{~kW}$, while the specific energy decreased from 15.68 to 14.50 and from 13.85 to $12.98 \mathrm{~kW} . \mathrm{h} / \mathrm{Mg}$, for Giza-171 and Sakha-105, respectively, at constant drum speed of $850 \mathrm{rpm}$ and feed rate of $1.6 \mathrm{Mg} / \mathrm{h}$. The increase in both power and specific energy by increasing grain moisture content is attributed to the excessive load of grains on the machine devices which consumed more energy.

\subsection{Effect of some operating parameters on milling criterion cost at} different rice varieties:

A complete cost analysis was made at different operating conditions and related with machine productivity. The resulting operating cost was found to be affected by both feed rate and power. Representative values of criterion cost versus feed rate, drum speed and grain moisture content at different rice varieties are given in Fig.8. The criterion cost was the sum of operational cost and grain losses cost. Concerning to the effect of feed rate on the criterion cost, increasing feed rate from 1.2 to $1.4 \mathrm{Mg} / \mathrm{h}$ the criterion cost 


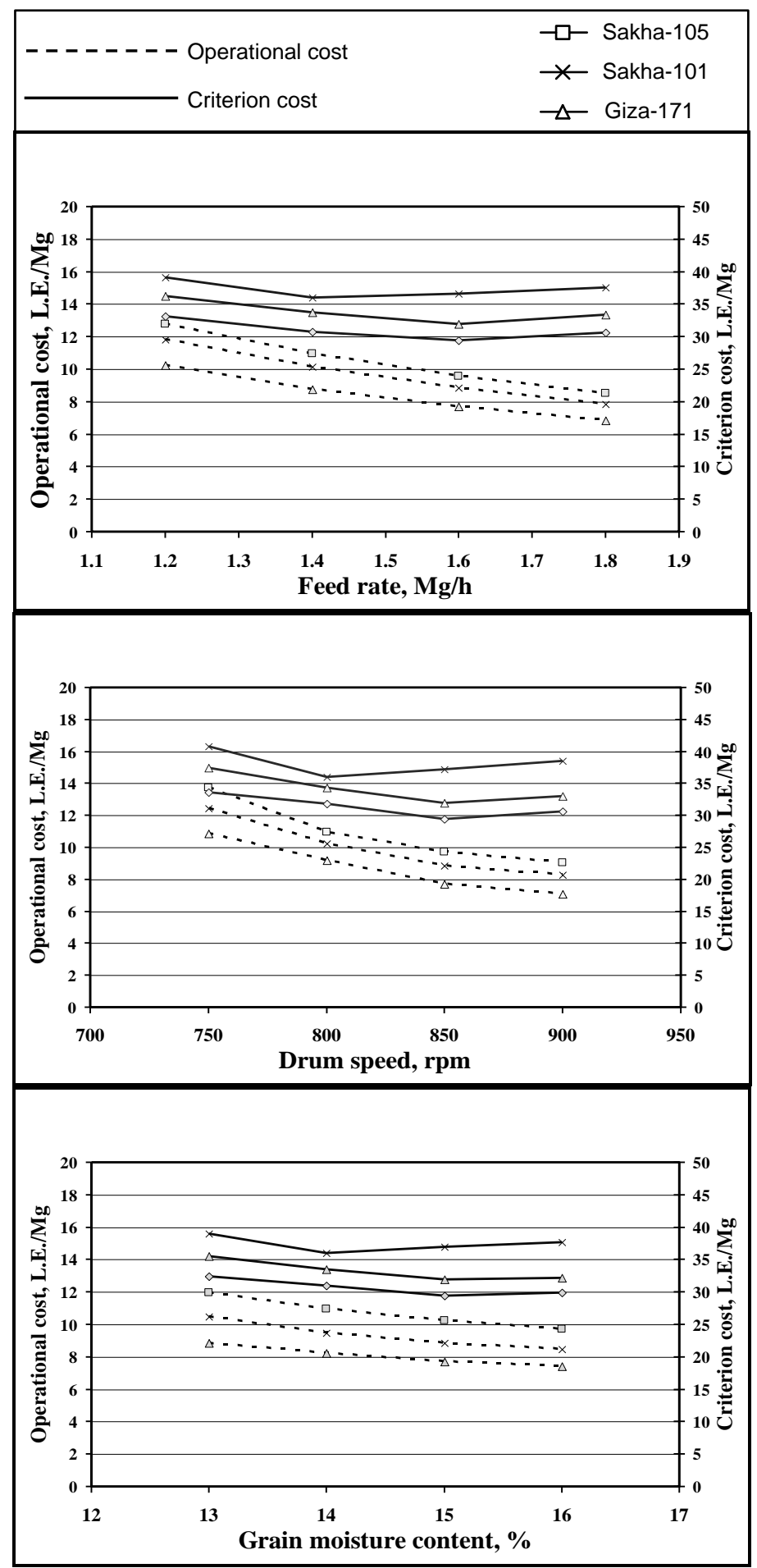

Fig.8. Effect of some operating parameters on operational and criterion cost at different rice varieties. 
decreased from 39.09 to 35.96 L.E/Mg for Sakha-101 variety. Any further increase in feed rate more than 1.4 up to $1.8 \mathrm{Mg} / \mathrm{h}$ increased criterion cost from 35.96 to $37.53 \mathrm{~L} . \mathrm{E} / \mathrm{Mg}$ at constant drum speed of $800 \mathrm{rpm}$ and grain moisture content of $14 \%$. While, for the other rice verities of Giza-171 and Sakha-105, increasing feed rate from 1.2 to $1.6 \mathrm{Mg} / \mathrm{h}$ the criterion cost decreased from 36.20 to 31.96 L.E/Mg and from 33.18 to 29.38 L.E/Mg, respectively. Any further increase in feed rate more than 1.6 up to $1.8 \mathrm{Mg} / \mathrm{h}$ the criterion cost increased from 31.96 to $33.37 \mathrm{~L} . \mathrm{E} / \mathrm{Mg}$ and from 29.38 to $30.57 \mathrm{~L} . \mathrm{E} / \mathrm{Mg}$ with the same rice varieties at constant drum speed of $850 \mathrm{rpm}$, grain moisture content of $15 \%$.

Relating to the effect of drum speed on the criterion cost, increasing drum speed from 750 to $800 \mathrm{rpm}$ the criterion cost decreased from 40.75 to 35.96 L.E/Mg for Sakha-101 variety. Any further increase in drum speed more than 800 up to $900 \mathrm{rpm}$ increased criterion cost from 35.96 to 38.53 L.E/Mg at constant feed rate of $1.4 \mathrm{Mg} / \mathrm{h}$ and grain moisture content of 14 $\%$. While, for the other rice verities of Giza-171 and Sakha-105, increasing drum speed from 750 to $850 \mathrm{rpm}$ the criterion cost decreased from 37.45 to 31.96 L.E/Mg and from 33.59 to 29.38 L.E/Mg, respectively. Any further increase in drum speed more than 850 up to 900 rpm the criterion cost increased from 31.96 to 33.3705 L.E/Mg and from 29.38 to $30.58 \mathrm{~L} . \mathrm{E} / \mathrm{Mg}$ with the same rice varieties at constant feed rate of $1.6 \mathrm{Mg} / \mathrm{h}$, grain moisture content of $15 \%$.

With Regard to the effect of grain moisture content on the criterion cost, increasing grain moisture content from 13 to $14 \%$ the criterion cost decreased from 38.96 to 35.96 L.E/Mg for Sakha-101 variety.

Any further increase in grain moisture content more than 14 up to $16 \%$ rpm increased criterion cost from 35.96 to $37.69 \mathrm{~L} . \mathrm{E} / \mathrm{Mg}$ at constant drum speed of $850 \mathrm{rpm}$ and feed rate $1.4 \mathrm{Mg} / \mathrm{h}$. While, for the other rice verities of Giza-171 and Sakha-105, increasing grain moisture content from 13 to $15 \%$ the criterion cost decreased from 35.47 to $31.96 \mathrm{~L} . \mathrm{E} / \mathrm{Mg}$ and from 32.36 to 29.38 L.E/Mg, respectively. Any further increase in grain 
moisture content more than 15 up to $16 \%$ the criterion cost increased from 31.96 to 32.20 L.E/Mg and from 29.38 to $29.93 \mathrm{~L}$.E/Mg with the same rice varieties at constant drum speed of $850 \mathrm{rpm}$ and feed rate of 1.6 $\mathrm{Mg} / \mathrm{h}$. Both higher and lower values of drum speed, feed rate and grain moisture content more than or less to the optimum value tend to increase criterion cost due to the increase in total grain losses.

\section{CONCLUSION}

A rice milling machine was developed to maximize product quality. A cleaning unit was constructed and located before the feed hopper of the rice milling machine to clean up the rice grains before milling process. The machine performance was evaluated using three rice varieties. From obtained results, the following conclusions can be taken:

- The highest values of machine productivity and overall machine efficiency were $1.08,1.17$ and $1.35 \mathrm{Mg} / \mathrm{h}$; and $95.00,95.38$ and 95.66 $\%$ for Sakha-101, Giza-171 and Sakha-105 varieties, respectively.

- The lowest values of required power and specific energy were 13.0, 13.4 and $13.8 \mathrm{~kW}$; and 17.40, 15.68 and $13.85 \mathrm{~kW} . \mathrm{h} / \mathrm{Mg}$, respectively, for the same rice varieties.

- The lowest values of both operational and criterion costs were 8.53, 7.87 and 6.82 L.E./Mg; and 35.96, 31.96 and 29.38 L.E./Mg, respectively, for the same rice varieties.

\section{REFERRENCES}

Appiah, F; R. Guisse and P. K. A. Dartey (2011): Post harvest losses of rice from harvesting to milling in Ghana. Journal of Stored Products and Postharvest Research, 2 (4): 64-71.

Awady, M. N. (1978): Tractor and farm machinery. Text book, Faculty of Agriculture, Ain-Shams University. Pp: 164-167.

Awady, M. N; E. Y. Ghoniem, and A. I. Hashish (1982): Agriculture comparison between wheat combine harvesters under Egyptian conditions. Res. Bul. Ain-Shams Univ.:13p. 
El-Raie, A. E. S; N. A. Hendawy and A.Z. Taib (1996). Study of physical and engineering properties for some agricultural products. Misr. J. Ag. Eng., 13 (1):211- 226.

Klenin, N. I; I. F. Popov and V.A. Sukun (1985). Agricultural machines. Theory of operation, computation of controlling parameters and the conditions of operation. Amerind publishing Co. PVT. Ltd., New Delhi.

Radwan, S. M. (2001): The potential energy consumption for milling some Egyptian rice varieties. Misr J. Ag. Eng., 18(3): 537-551.

Soltanabadi, M. H. and A. Hemmat (2007): Effect of blade distance and output rate on rice quality in a modified blade-type milling machine. Journal of Science and Technology of Agriculture and Natural Resources, 11 (1 A): 135-146.

Varnamkhasti, M. G; H. Mobli, A. Jafari, M. H. Soltanabadi, A. Keyhani and S. Kaffee (2007): Processing quality of milled rice in modified blade type milling machine considering variety type, rotor speed, and output flow rate. Proceedings of the International Agricultural Engineering Conference, Bangkok, Thailand, 3-6 December.

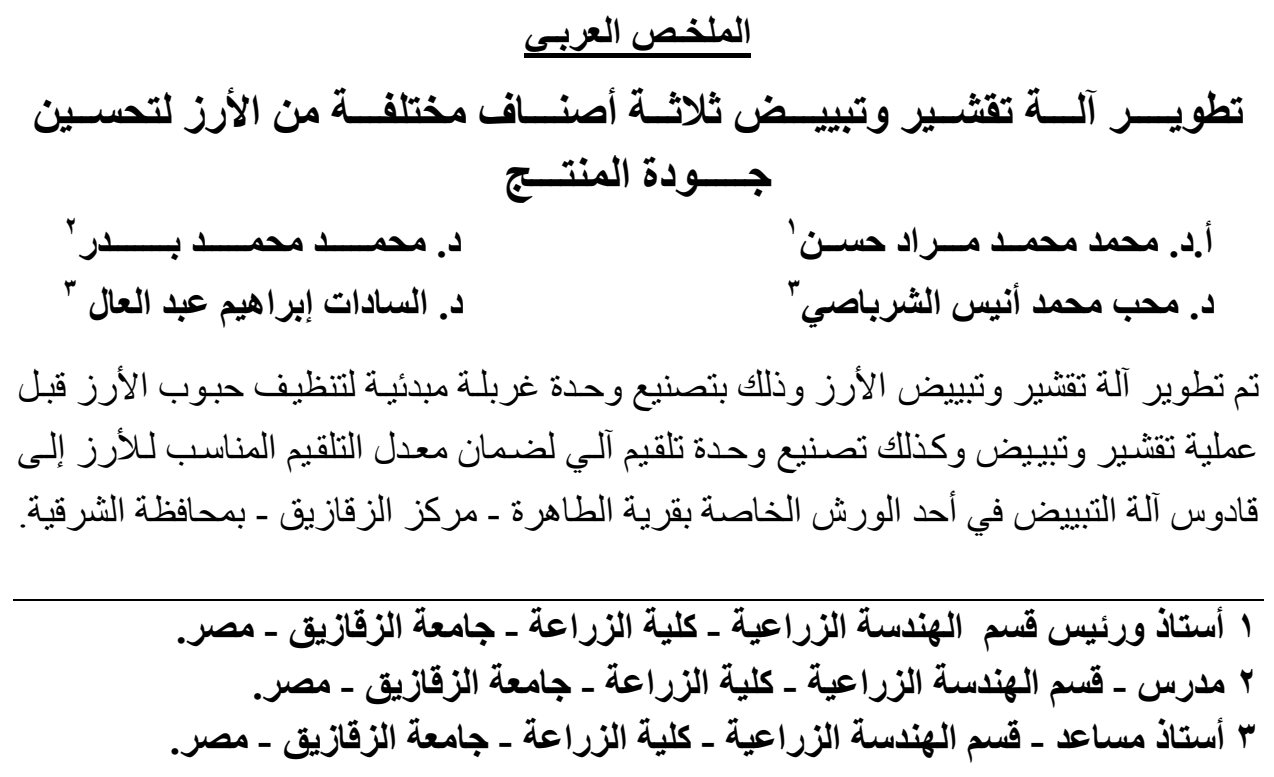


تم دراسة بعض الخصائص الطبيعية و الهندسية لأصناف الأرز تحت الدراسـة لمعرفة السرعة المناسبة لمروحة التنظيف وكذللك السرعة المثلى لغر ابيل التنظيف. وفيما يلي الأهداف الخاصة بهذه الاراسة: • تطوير آلة تقشير وتبييض الأرز وذللك بتصنيع وحدة غربلة لتنظيف الأرز مكونة من مروحة

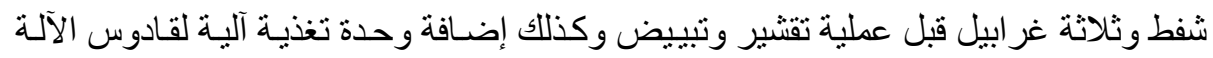
لضمان معدل التلقيم المناسب.

• تحديد سر عة الهو اء المثلى لمروحة الثفط وكذللك سر عة وميل غر ابيل التنظيف. • تحديد القيم المثلى لكل من معدل التلقيم وسر عة الدرفيل ونسبة الرطوبـة للحبوب و التى تئثر على أداء الآلة لثلاثة أصناف من الأرز تحت معن الدراسة. • تقييم آلة ضرب الأرز من المنظور الاقتصادي.

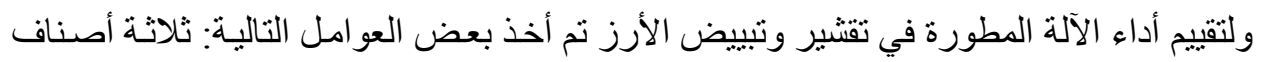

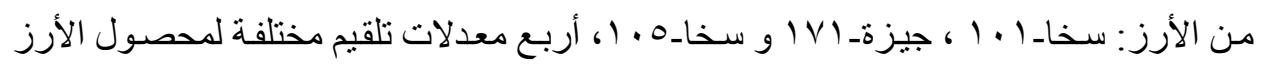

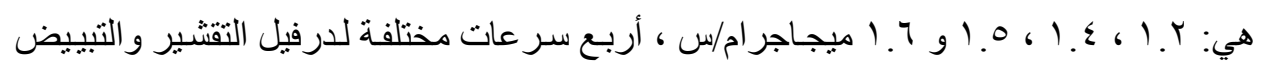

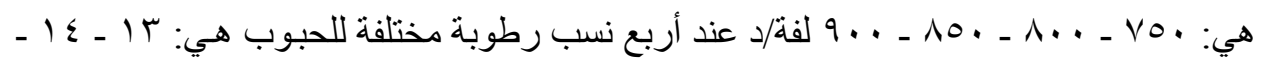
$\% 17-10$

تم أخذ القياسات التالية: الفو اقد الكلية لحبوب الأرز، الكفاءة الكلية لآلة ضرب الأرز ، الإنتاجيـة ،

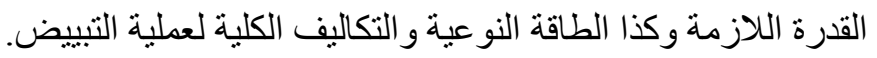

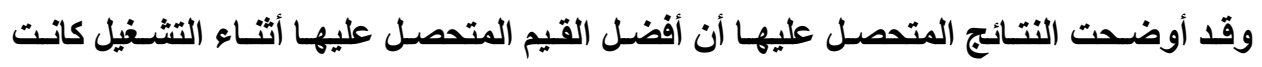
كالتالي:

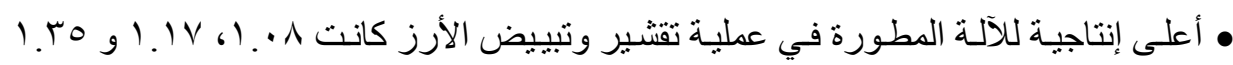

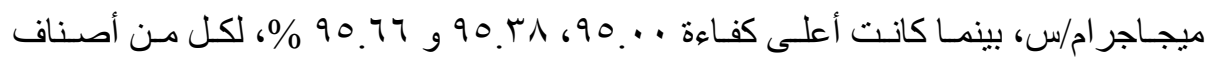

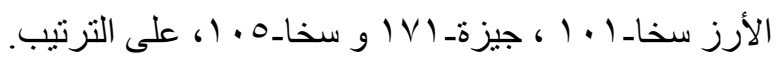

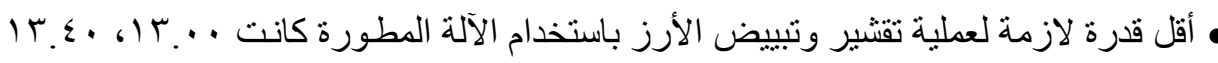

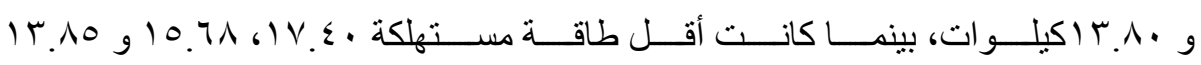

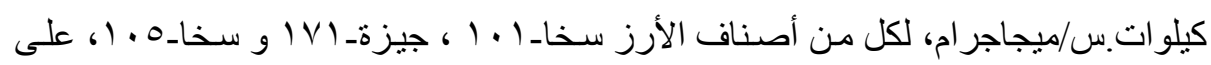
الترنيب.

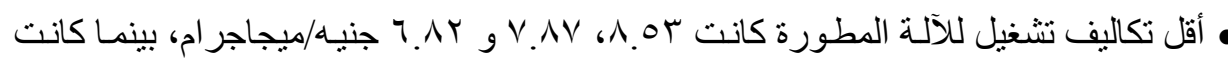

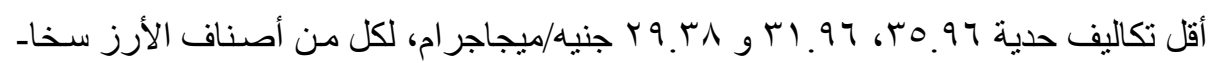

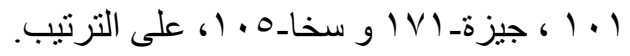




\section{ومما تقام توصى الدراسة بما يلي:}

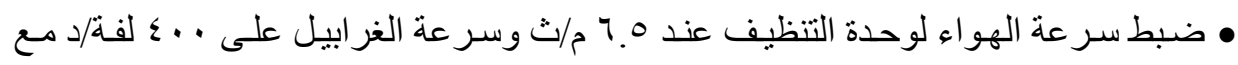

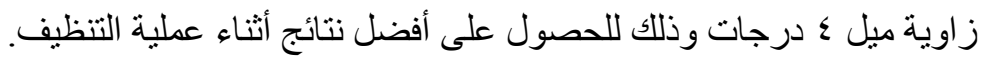

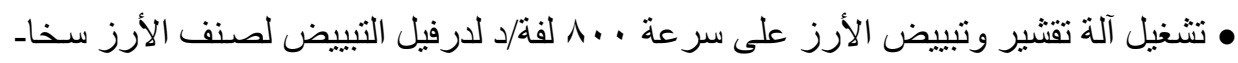

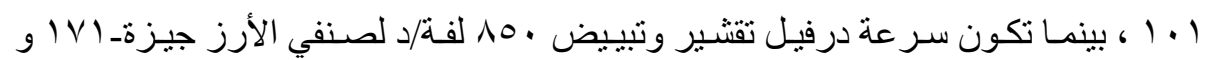
سخا_0.

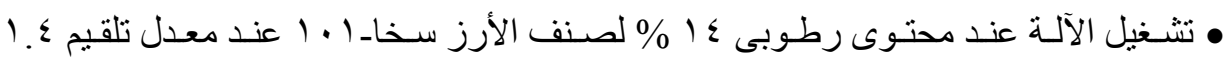

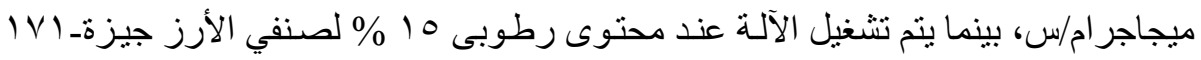

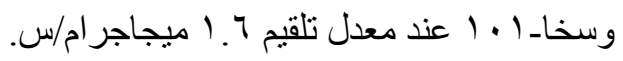

